OPEN ACCESS

Edited by:

Francisco Rodriguez-valera, Universidad Miguel Hernández

de Elche, Spain

Reviewed by:

Aharon Oren,

The Hebrew University of Jerusalem,

Israel

Uri Gophna

Tel Aviv University, Israel

*Correspondence:

Rosa María Martínez-Espinosa

rosa.martinez@ua.es

Specialty section:

This article was submitted to

Biology of Archaea,

a section of the journal

Frontiers in Microbiology

Received: 10 February 2020

Accepted: 31 March 2020

Published: 22 April 2020

Citation:

Torregrosa-Crespo J, Pire C

Bergaust $L$ and

Martínez-Espinosa RM (2020)

Haloferax mediterranei, an Archaeal

Model for Denitrification in Saline

Systems, Characterized Through

Integrated Physiological

and Transcriptional Analyses.

Front. Microbiol. 11:768.

doi: 10.3389/fmich.2020.00768

\section{Haloferax mediterranei, an Archaeal Model for Denitrification in Saline Systems, Characterized Through Integrated Physiological and Transcriptional Analyses}

\author{
Javier Torregrosa-Crespo ${ }^{1}$, Carmen Pire ${ }^{2}$, Linda Bergaust ${ }^{2}$ and \\ Rosa María Martínez-Espinosa ${ }^{1 *}$ \\ ${ }^{1}$ Department of Agrochemistry and Biochemistry, Faculty of Science, University of Alicante, Alicante, Spain, ${ }^{2}$ Faculty \\ of Chemistry, Biotechnology and Food Science, Norwegian University of Life Sciences, Ås, Norway
}

Haloferax mediterranei (R4) belongs to the group of halophilic archaea, one of the predominant microbial populations in hypersaline environments. In these ecosystems, the low availability of oxygen pushes the microbial inhabitants toward anaerobic pathways and the presence of $\mathrm{N}$-oxyanions favor denitrification. In a recent study comparing three Haloferax species carrying dissimilatory $\mathrm{N}$-oxide reductases, $H$. mediterranei showed promise as a future model for archaeal denitrification. This work further explores the respiratory physiology of this haloarchaeon when challenged with ranges of nitrite and nitrate concentrations and at neutral or sub-neutral $\mathrm{pH}$ during the transition to anoxia. Moreover, to begin to understand the transcriptional regulation of $\mathrm{N}$-oxide reductases, detailed gas kinetics was combined with gene expression analyses at high resolution. The results show that $H$. mediterranei has an expression pattern similar to that observed in the bacterial Domain, well-coordinated at low concentrations of $\mathrm{N}$-oxyanions. However, it could only sustain a few generations of exponential anaerobic growth, apparently requiring micro-oxic conditions for de novo synthesis of denitrification enzymes. This is the first integrated study within this field of knowledge in haloarchaea and Archaea in general, and it sheds lights on denitrification in salty environments.

Keywords: Haloferax, denitrification, nitrogenous gases, nitrate reductase, nitrite reductase, extremophile

\section{INTRODUCTION}

The ability to maintain a respiratory metabolism in lieu of oxygen is widespread. Among the many types of anaerobic dissimilatory pathways, denitrification is the most energetically profitable. Complete denitrification is the stepwise reduction of nitrate $\left(\mathrm{NO}_{3}{ }^{-}\right)$to dinitrogen $\left(\mathrm{N}_{2}\right)$ via nitrite $\left(\mathrm{NO}_{2}{ }^{-}\right)$, nitric oxide (NO), and nitrous oxide $\left(\mathrm{N}_{2} \mathrm{O}\right)$ (Zumft and Kroneck, 2006; Philippot et al., 2007; Bakken et al., 2012). Despite its ubiquity, our knowledge about the "nuts and bolts" of the process is based on detailed studies of a few model organisms, mainly proteobacteria with mesophilic lifestyles. The role of denitrification in nitrogen turnover and $\mathrm{N}$-oxide emission have been studied at length in environments such as agricultural or forestry soils (Bru et al., 2007; Samad et al., 2016; Roco et al., 2017). Less is known about saline and hypersaline ecosystems, 
where anaerobic respiration is prominent because the high salt concentrations result in low oxygen availability (RodríguezValera et al., 1985; Sherwood et al., 1991, 1992; Oren, 2013). Such systems are becoming increasingly interesting in terms of denitrification and $\mathrm{N}$-oxide emissions because anthropogenic activities currently lead to contamination by nitrogenous compounds like nitrates and nitrites (MartínezEspinosa et al., 2007; Ochoa-Hueso et al., 2014; TorregrosaCrespo et al., 2018). Moreover, their extent on a global scale is on the rise due to desertification, resulting from climate change (Torregrosa-Crespo et al., 2018).

Hypersaline environments accommodate representatives of all the three Domains of Life, but when the salt concentration exceeds 16\%, haloarchaea dominate (Andrei et al., 2012; Edbeib et al., 2016; Torregrosa-Crespo et al., 2019). Among them are several denitrifiers and the microorganism that has emerged as a representative model is Haloferax mediterranei. It has the full set of metalloenzymes to catalyze the reduction of $\mathrm{NO}_{3}{ }^{-}$to $\mathrm{N}_{2}$ : the membrane-bound nitrate reductase facing the pseudo periplasm (NAR) (Lledó et al., 2004; Martínez-Espinosa et al., 2007), the copper-containing nitrite reductase (NIR) (Martínez-Espinosa et al., 2006), the nitric oxide reductase (NOR) (TorregrosaCrespo et al., 2017), and the nitrous oxide reductase $\left(\mathrm{N}_{2} \mathrm{OR}\right)$ (Torregrosa-Crespo et al., 2016). Currently, it is one out of very few archaea for which detailed phenotypic data exist, and it is the only one which has been shown to be a complete denitrifier, able to reduce $\mathrm{NO}_{3}{ }^{-}$to $\mathrm{N}_{2}$ while displaying low and transient accumulation of the gaseous intermediates $\mathrm{NO}$ and $\mathrm{N}_{2} \mathrm{O}$ (Torregrosa-Crespo et al., 2019). This opens the door to further exploration of its respiratory physiology and regulation of denitrification.

Like its bacterial counterparts, $H$. mediterranei carry nar, nir, nor, and nos gene clusters encoding the four structural enzymes of denitrification (Lledó et al., 2004; Martínez-Espinosa et al., 2006; Torregrosa-Crespo et al., 2016). However, unlike some of the well-studied proteobacteria (Bergaust et al., 2008; Qu et al., 2016), little is known about the expression of the functional denitrification genes during the transition from aerobic to anaerobic respiration, or the effect of $\mathrm{pH}$ and electron acceptor concentrations on $\mathrm{N}$-oxide accumulation. Through a combination of gene expression analyses and detailed physiological studies, this work begins to remedy this, finding evidence to suggest that regulatory similarities exist across domains. Thus, it bears implications for our understanding of denitrification in archaea in general, and in a representative of the halophilic community in particular.

\section{MATERIALS AND METHODS}

\section{Physiological Experiments Testing Different $\mathrm{NO}_{3}{ }^{-}$and $\mathrm{NO}_{2}{ }^{-}$Concentrations and $\mathrm{pH}$ Values Culturing Conditions}

Haloferax mediterranei (R4) was raised in a complex medium [20\% (w/v) mixture of salts and $0.5 \%(\mathrm{w} / \mathrm{v})$ yeast extract]
(Rodríguez-Valera et al., 1980; DasSarma et al., 1995), pH 7.3 at $35^{\circ} \mathrm{C}$ under aerobic conditions, with vigorous stirring (700 r/min) using a triangular magnetic stirring bar (Cowie $25 \times 8 \mathrm{~mm}$, VWR International) to ensure full dispersal of cells and oxic conditions. Moreover, the aerobic pre-cultures were never allowed to grow beyond densities of $1.94 \times 10^{8}$ cells $\mathrm{mL}^{-1}$.

Aerobic pre-cultures were transferred to $120 \mathrm{ml}$ serum vials containing a triangular magnetic stirring bar and $50 \mathrm{ml}$ medium at $35^{\circ} \mathrm{C}$. All cultures were continuously stirred at $700 \mathrm{r} / \mathrm{min}$, to avoid aggregation. The media contained different $\mathrm{KNO}_{3}$ or $\mathrm{KNO}_{2}$ concentrations depending on the assay: 2, 5, 10, 20, 200, and $2000 \mathrm{mM} \mathrm{KNO}_{3} ; 1,2,5,10$, and $40 \mathrm{mM} \mathrm{KNO}_{2}$. The $\mathrm{pH}$ was 7.3 (optimum for $H$. mediterranei) for all the experiments and the media were always buffered with Bis-Tris $100 \mathrm{mM}$. The different $\mathrm{pH}$ values for the experiments to test the effect of this parameter on denitrification were: $7.3,7.0,6.5$.

Vials were crimp sealed with rubber septa (Matriks AS, Norway) and aluminum caps to ensure an airtight system. The vials were made anoxic by repeated cycles of evacuation and helium (He) filling with constant stirring to ensure optimal gas exchange between liquid and headspace. The initial availability of gaseous electron acceptors was then adjusted by injection of pure $\mathrm{O}_{2}$ and in some instances $\mathrm{N}_{2} \mathrm{O}$. All experiments were conducted under atmospheric pressure at $35^{\circ} \mathrm{C}$.

\section{Gas Measurements and Apparent Specific Growth Rates}

The gas measurements were done in a robotized incubation system similar to that described by Molstad et al. (2007), with some improvements. The system monitored the headspace concentrations of relevant gases $\left(\mathrm{O}_{2}, \mathrm{CO}_{2}, \mathrm{NO}, \mathrm{N}_{2} \mathrm{O}\right.$, and $\left.\mathrm{N}_{2}\right)$ by repeated gas sampling through the butyl rubber septa of the incubation vials (30 stirred vials). The gas samples were drawn by a peristaltic pump coupled to an autosampler (Agilent GC Sampler 80), and with each sampling an equal volume of He was pumped back into the vials. This secured that the gas pressure was sustained near 1 atm despite repeated sampling but diluted the headspace atmosphere (with $\mathrm{He}$ ). This dilution was considered when calculating the rates of production/consumption for each time increment (see Molstad et al., 2007 for details). The sampling system was coupled to a gas chromatograph (GC) (Agilent GC-7890A) with $30 \mathrm{~m} 0.53 \mathrm{~mm}$ id columns: a porous layer open tubular (PLOT) column for separation of $\mathrm{CH}_{4}$. $\mathrm{NO}$ was measured by a chemiluminescence $\mathrm{NO}_{\mathrm{x}}$ analyzer (M200A or M200E, Teledyne).

Nitrite was measured by injecting $10 \mu$ l liquid sample into a purge vessel containing $3 \mathrm{ml}$ reducing agent $(\mathrm{NaI}, 1 \% \mathrm{w} / \mathrm{v}$ in acetic acid) connected to a chemiluminescence detector (Nitric Oxide Analyzer NOA 280i, General Electric). $\mathrm{N}_{2}$ was continuously bubbled through the reducing agent to maintain an anoxic environment in the system and to transport the NO through the NO analyzer (Walters et al., 1987).

Apparent specific aerobic $\left(\mu_{\mathrm{ox}}\right)$ and anaerobic $\left(\mu_{\text {anox }}\right)$ growth rates were estimated based on the observed kinetics of $\mathrm{O}_{2}$ consumption and denitrification, respectively, through the 
regression of $\log (\ln )$ transformed respiration rates versus time during log-linear increases in electron transport rates.

\section{Gas Kinetics and Transcription of narG, nirk, nor Z, and nosZ Genes During $\mathrm{O}_{2}$ Depletion and Subsequent Denitrification}

A total of 15 anoxic vials containing media supplemented with $5 \mathrm{mM} \mathrm{KNO}_{3}$ were injected with pure $\mathrm{O}_{2}$ to approximately 1 vol\% in headspace and then inoculated with $2 \cdot 10^{8}$ cells from aerobic pre-cultures. Cultures were placed in the robotized incubation system at $35^{\circ} \mathrm{C}$, with continuous stirring at $700 \mathrm{r} / \mathrm{min}$, and the gas kinetics in each vial was monitored by headspace measurements (1- to 3-h intervals). Samples for gene expression analysis (50, 10 , 5 , or $2 \mathrm{ml}$ depending on cell density) were harvested at frequencies guided by the observed gas kinetics; at each time, cells were taken from three separate vials and considered biological replicates. Entire vials were sacrificed for 50 and $10 \mathrm{ml}$ samples, whereas a maximum of two $5 \mathrm{ml}$ samples were taken before vials were excluded from further gas measurements. Nitrite concentration and cell densities $\left(\mathrm{OD}_{600}\right)$ were measured for each sample. Three replicates were left undisturbed by liquid sampling and only headspace gases were monitored.

\section{Gene Expression Analysis}

Guided by the observed gas kinetics, samples $(50,10$, 5, or $2 \mathrm{ml}$, depending on cell density) were taken from the liquid phase of the vials throughout the experiment, as well as from the inoculum (time: $0 \mathrm{~h}$ ). Samples were transferred to chilled, sterile 50 or $2 \mathrm{ml}$ centrifugation tubes. One milliliter of the sample was taken to measure $\mathrm{OD}_{600}$ and $\mathrm{NO}_{2}{ }^{-}$concentration. The remaining sample volume was pelleted by centrifugation $(10,000 \times g, 10 \mathrm{~min})$ at $4{ }^{\circ} \mathrm{C}$. The supernatant was decanted, and $1 \mathrm{ml}$ of a mixture of RNA protect Bacteria Reagent (Qiagen) with salty water $20 \% \mathrm{w} / \mathrm{v}$ (Rodríguez-Valera et al., 1980; DasSarma et al., 1995) in a 1:1 ratio was added to the cell pellet. After treatment with RNAprotect, the cells were pelleted once more by centrifugation $(10,000 \times g$, $10 \mathrm{~min}$ ) at room temperature and then stored at $-20^{\circ} \mathrm{C}$ awaiting RNA extraction. Due to the considerable number of samples, the biological replicates were divided into three times series; RNA extraction and DNAse treatment were done in three rounds, whereas for reverse transcription, all samples were collected and processed in one round. Total RNA was extracted from all samples using the RNeasy Mini Kit (Qiagen) and residual DNA removed by DNase treatment (TURBO DNA-free, Ambion) according to the suppliers' instructions. The concentration of total RNA was measured using the Qubit RNA BR assay and a Qubit fluorometer (Invitrogen). Absence of gDNA was confirmed in each sample by real-time PCR targeting the nor $Z$ gene, using RNA that had not been reverse transcribed. Reverse transcription was performed using a SuperScript VILO cDNA Synthesis Kit (Invitrogen). Droplet Digital PCR (ddPCR) ${ }^{\mathrm{TM}}$ was performed on a QX200 ddPCR ${ }^{\text {TM }}$ System (Bio-Rad) using BioRad's QX200 ddPCR EvaGreen supermix and primers to target narG, nirk, norB, and nosZ (Supplementary Table S3). The expression of each gene was calculated by absolute quantification. ddPCRs were set up in technical triplicate for each of the three biological replicates and normalized by (RNAtotal) ng sample ${ }^{-1}$.

\section{Aerobic $\mathrm{N}_{2} \mathrm{O}$ Reduction in Early Denitrification}

Pre-culturing and gas measurements of batch cultures were carried out as described in Section "Physiological Experiments Testing Different $\mathrm{NO}_{3}{ }^{-}$and $\mathrm{NO}_{2}{ }^{-}$Concentrations and $\mathrm{pH}$ Values." The aerobically raised cells were transferred to He-rinsed vials containing $50 \mathrm{ml}$ complex medium with $5 \mathrm{mM} \mathrm{KNO}_{3}$, and with 1 vol\% $\mathrm{O}_{2} 100$ ppmv $\mathrm{N}_{2} \mathrm{O}$ (in triplicate). Cell-free vials were also included in triplicate for each treatment to provide accurate estimates of sampling dilution. Gas kinetics was monitored every $3.6 \mathrm{~h}$ in the robotized incubation system described under Section "Gas Measurements and Apparent Specific Growth Rates."

\section{RESULTS}

\section{Effect of Nitrate Concentration on Denitrification in $\boldsymbol{H}$. mediterranei}

Haloferax mediterranei was exposed to different initial concentrations of nitrate (ranging from $2 \mathrm{mM}$ to $2 \mathrm{M} \mathrm{KNO}_{3}$ ) with 1 vol\% initial $\mathrm{O}_{2}$ in the headspace, and aerobic respiration and denitrification was monitored by frequent gas measurements (Molstad et al., 2007). Nitrate concentrations did not severely affect the accumulation of gaseous intermediates during the oxic-anoxic transition or subsequent denitrification (Figure 1A and Supplementary Table S1A). However, the two most extreme treatments ( 0.2 and $2 \mathrm{M}$ initial nitrate) led to a subtle increase in the transient $\mathrm{NO}$ peak following oxygen depletion $\left(\mathrm{NO}_{\max }\right)$ as well as in the average NO concentration during balanced anaerobic growth $\left(\mathrm{NO}_{\text {steady }}\right)$. There was an approximate doubling and ten-fold increase in the accumulation of $\mathrm{N}_{2} \mathrm{O}$ in 0.2 and $2 \mathrm{M}$ cultures, respectively, compared to $2-20 \mathrm{mM}$ cultures, with observed $\mathrm{N}_{2} \mathrm{O}_{\max }$ of $0.21 \pm 0.03$ and $1.06 \pm 0.08 \mu \mathrm{mol}$ $\mathrm{N}_{2} \mathrm{O}-\mathrm{N} \mathrm{vial}^{-1}$ in the high nitrate cultures (Supplementary Table S1A). The accumulation of nitrite $\left(\mathrm{NO}_{2}{ }^{-}\right.$max $)$increased with initial nitrate concentration up to $10 \mathrm{mM}$ but was apparently not affected beyond that point. The apparent decrease in cultures with $2 \mathrm{M}$ initial nitrate most likely does not reflect the actual $\mathrm{NO}_{2}{ }^{-}$max , because nitrite was still increasing at the end of the experiment (Figure 1A).

The e- flow toward terminal electron acceptors $\left(\mathrm{Ve}^{-}, \mu \mathrm{mol}\right.$ vial $^{-1} \mathrm{~h}^{-1}$ ) was derived from the gas data and used to estimate the apparent specific growth rates during aerobic respiration and denitrification, $\mu_{\mathrm{ox}}$ and $\mu_{\text {anox }} \mathrm{h}^{-1}$, respectively. $\mu_{\mathrm{ox}}$ was largely unaffected by nitrate concentrations up to $0.2 \mathrm{M}$ $\left(\mu_{\mathrm{ox}}=0.201 \pm 0.020 \mathrm{~h}^{-1}\right.$; average generation times $\mathrm{G}(\mathrm{t}) \sim$ $3.5 \mathrm{~h}$ ). However, cultures with $2 \mathrm{M}$ nitrate displayed a clear decrease in $\mu_{\text {ox }}\left(0.115 \pm 0.019 \mathrm{~h}^{-1}\right)$ to a near doubling in $\mathrm{G}(\mathrm{t})(\sim 6.0 \mathrm{~h})$ (Figure 1B and Supplementary Table S1B). Likewise, $\mu_{\text {anox }}$ and thus $G(t)$ during denitrification was not significantly affected by nitrate within the range of 2-200 mM (Figure 1B, Supplementary Table S1B, and Supplementary Figure S1), although a weak negative trend was observed 


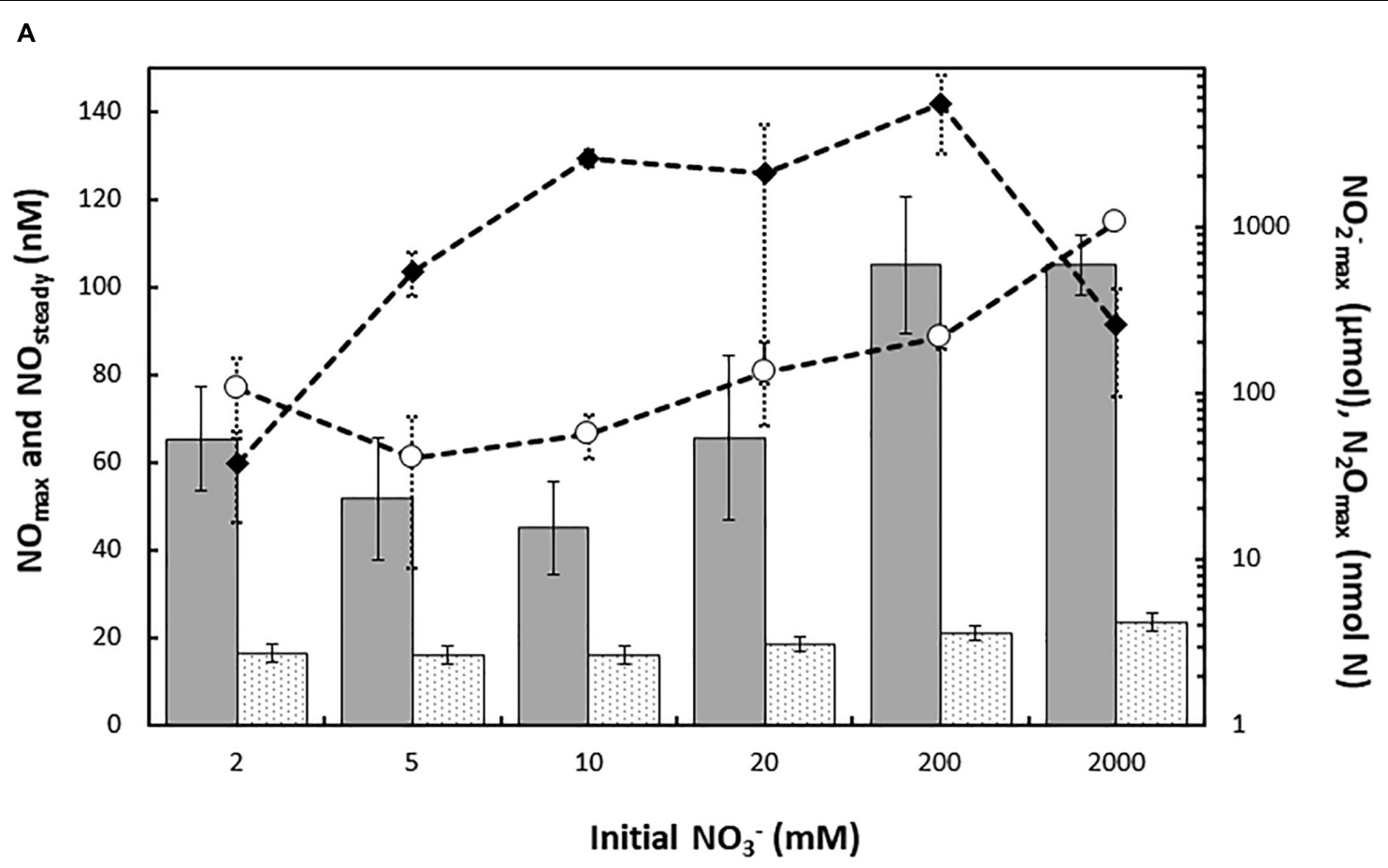

B

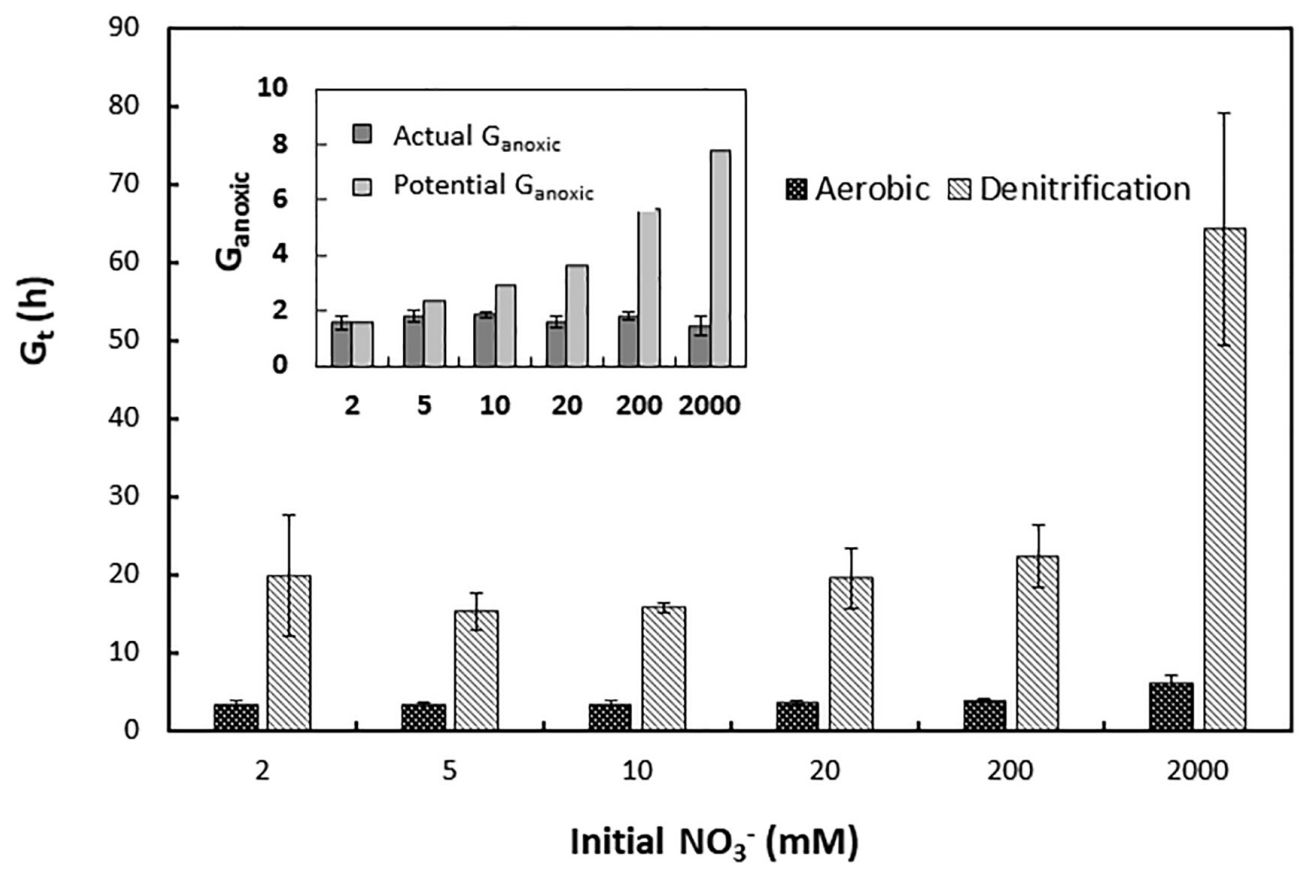

FIGURE 1 | (A) Accumulation of $\mathrm{N}$-oxide intermediates during denitrification in batch cultures of $\mathrm{H}$. mediterranei supplemented with different initial $\mathrm{KNO}_{3}$ concentrations (2-2000 mM). Bars, left $y$-axis: $\mathrm{NO}_{\max }$ (gray bars) and $\mathrm{NO}_{\text {steady }}$ (dotted bars; average $\mathrm{NO}$ concentration during exponential anaerobic growth), $\mathrm{nM}$ in liquid; plots, right $y$-axis (log-scale): $\mathrm{NO}_{2}^{-}$(black diamonds) and $\mathrm{N}_{2} \mathrm{O}_{\max }$ (circles), $\mu \mathrm{mol}$ and $\mathrm{nmol} \mathrm{N}$ vial ${ }^{-1}$, respectively. (B) Generation time (Gt, h) and duration of apparent exponential growth by denitrification in $\mathrm{H}$. mediterranei supplemented with 2-2000 $\mathrm{mM} \mathrm{KNO}_{3}$. Main panel: generation time (h) during aerobic respiration (black bars) and denitrification (gray patterned bars), derived from apparent specific growth rates $\left(\mu \mathrm{h}^{-1}\right)$. Oxic and anoxic $\mu \mathrm{h}^{-1}$ were estimated based on the In transformed e-flow rate to terminal electron acceptors during the exponential phase of oxygen respiration and denitrification, respectively. Insert: estimated actual (dark gray bars) and potential (light gray bars) generations of exponential growth by denitrification ( $\mathrm{G}_{\text {anoxic }}$ ) across nitrate treatments. For the cultures with $2 \mathrm{M}$ nitrate, denitrification rate was still exponential at the end of the experiment, leading to a likely underestimation of actual $G_{\text {anoxic }}$. 
(Supplementary Figure S1, insert). However, the cultures with $2 \mathrm{M}$ nitrate showed a dramatic decrease in apparent anaerobic growth rate, with an approximate $300 \%$ increase in average generation time relative to $2-200 \mathrm{mM}$ cultures (Figure 1B).

The addition of high amounts of nitrate should support multiple generations of exponential anaerobic growth $\left(G_{\text {anoxic }}\right)$, in proportion to initial nitrate concentration. However, regardless of the amount of nitrate available, $H$. mediterranei did not maintain exponential growth by denitrification beyond 1.5-2 generations (Figure 1B, insert). The electron flow ( $\mu \mathrm{mol} \mathrm{e}^{-}$ vial $^{-1} \mathrm{~h}^{-1}$ ) toward NAR and NIR were derived from the gas data for cultures supplemented with 2, 5, and $10 \mathrm{mM} \mathrm{KNO}_{3}$, respectively (Figure 2). In cultures with $2 \mathrm{mM}$ nitrate (Figure 2A, left panel), both NAR and NIR rates increased exponentially until they stopped due to depletion of nitrate, whereas in cultures with 5 and $10 \mathrm{mM}$ initial nitrate (Figures 2B,C, left panels), NIR reached a plateau stage first, while the relative NAR activity was still increasing. Toward the end of the incubations in cultures with $5 \mathrm{mM}$ nitrate, NAR activity stopped before NIR due to nitrate depletion. During balanced denitrification where NAR and NIR operate at equal rates, Ve-NAR/Ve-NIR $=2$ (two electrons to reduce $\mathrm{NO}_{3}{ }^{-}$to $\mathrm{NO}_{2}{ }^{-}$and one electron to reduce $\mathrm{NO}_{2}{ }^{-}$to $\mathrm{NO}$ ). In cultures supplemented with $2 \mathrm{mM} \mathrm{KNO}_{3}$, the ratio was 2 throughout the incubation (Figure $2 \mathrm{~A}$, right panel), whereas in the rest of the cultures, it increased when the electron flow toward NIR reached the plateau (Figures 2B,C, right panels), reflecting higher NAR activity relative to NIR. Injection of $\mathrm{O}_{2}$ and $\mathrm{NO}$ after decline in denitrification rates had no significant effect, although there was a slight increase in e- flow to $\mathrm{N}$-oxides after addition of $\mathrm{O}_{2}$ (Supplementary Figure S2).

The $5 \mathrm{mM}$ nitrate treatment was selected for further exploration of denitrification in $H$. mediterranei: effect of $\mathrm{pH}$ on denitrification and transcription of functional denitrification genes during transition to anoxia and subsequent anaerobic growth.

In order to test the effect of $\mathrm{pH}$ on denitrification, $H$. mediterranei was exposed to a range of $\mathrm{pH}$ levels (7.3, 7.0, 6.5, 6.0, and 5.7) using $100 \mathrm{mM}$ Bis-Tris as buffer. $H$. mediterranei managed the transition to denitrification without any dramatic $\mathrm{pH}$ effects at $\mathrm{pH} \geq 6.5$, but at $\mathrm{pH}<6.5$, there was a general collapse of respiration upon oxygen depletion and the organism appeared unable to initiate denitrification (Supplementary Table S2A).

\section{Effect of Nitrite Concentration on Denitrification in $\boldsymbol{H}$. mediterranei}

A set of experiments was carried out using nitrite (ranging between 1 and $40 \mathrm{mM}$ ) as an alternative electron acceptor in the presence of $1 \mathrm{vol} \% \mathrm{O}_{2}$ in headspace. The presence of nitrite had a negative effect on the $\mathrm{O}_{2}$ consumption rate with an apparent log linear decline in $\mu_{\mathrm{ox}}$ with increasing nitrite concentration (Figure 3A, insert). Thus, while estimated $\mu_{\mathrm{ox}}$ in cultures with $1 \mathrm{mM}$ initial nitrite was $0.119 \pm 0.000 \mathrm{~h}^{-1}$ (approximately 50\% of the observed rate in nitrite-free cultures), with $10 \mathrm{mM}$ initial nitrite, the specific growth rate declined by approximately $76 \%$, to $0.028 \pm 0.004 \mathrm{~h}^{-1}$. In cultures with $40 \mathrm{mM}$ initial nitrite, the inhibition was severe with a $98 \%$ decrease in apparent aerobic growth rate $\left(0.002 \pm 0.001 \mathrm{~h}^{-1}\right)$ (Figure 3A).

During the anoxic phase at initial nitrite concentrations between 1 and $5 \mathrm{mM}, H$. mediterranei reduced all the available $\mathrm{NO}_{2}{ }^{-}$to $\mathrm{N}_{2}$. However, in the presence of $5 \mathrm{mM} \mathrm{KNO}_{2}$, the maximum concentration of nitric oxide increased significantly (to approximately $1.4 \mu \mathrm{M}$ ) (Figure 3B). The apparent anoxic growth rate was equal when comparing cultures with 2 and $5 \mathrm{mM}$ of $\mathrm{KNO}_{2}$ ( $\mu_{\text {anox }}$ between 0.09 and $0.10 \mathrm{~h}^{-1}$ respectively). However, as seen in cultures with $\geq 5 \mathrm{mM}$ nitrate, exponential growth ceased prematurely in the cultures with $5 \mathrm{mM}$ nitrite, while more than half of the added nitrite remained. Likewise, denitrification continued with declining $\mathrm{e}^{-}$flow rates to $\mathrm{N}$-oxides until nitrite depletion (Figures 3B,C and Supplementary Figure S3B). Finally, for the highest concentrations of nitrite tested (10 and $40 \mathrm{mM} \mathrm{KNO}_{2}$ ), $H$. mediterranei accumulated high concentrations of $\mathrm{NO}$ (up to $18 \mu \mathrm{M}$ in the liquid), with subsequent arrest in respiration (Supplementary Figure S4).

Using nitrite as terminal electron acceptor $(2 \mathrm{mM})$, the effect of $\mathrm{pH}$ in the slightly acidic to near- neutral range (5.7-7.3) was tested. In this case, low $\mathrm{pH}$ resulted in increased maximum concentrations of NO, reaching 490 and $960 \mathrm{nM}$ at $\mathrm{pH} 7.3$ and 6.5, respectively (Supplementary Table S2). At pH 6.5, some cultures were unable to respire nitrite after $\mathrm{O}_{2}$ depletion, whereas at $\mathrm{pH}<6.5$ both aerobic and anaerobic respiration failed.

\section{Transcription of narG, nirK, nor $Z$, and nos $Z$ Genes During $\mathrm{O}_{2}$ Depletion and Subsequent Denitrification}

The transcription of narG, nirK, nor $Z$, and nos $Z$ was monitored alongside gas kinetics and $\mathrm{NO}_{2}{ }^{-}$accumulation during the transition from aerobic to anaerobic respiration, and the conspicuous decline in growth rate during late anoxia. The cultures were supplemented with $5 \mathrm{mM}$ initial $\mathrm{KNO}_{3}$ and $1 \%$ initial $\mathrm{O}_{2}$.

The observed gas kinetics were as expected for $H$. mediterranei under the relevant conditions (Torregrosa-Crespo et al., 2019). The cultures reduced all available nitrate to $\mathrm{N}_{2}$ with minimal and transient accumulation of intermediates. Denitrification was initiated at low $\mathrm{O}_{2}(2.49 \pm 0.28 \mu \mathrm{M}$ in liquid $)$, as seen by transient peaks of $\mathrm{NO}$ and $\mathrm{N}_{2} \mathrm{O}\left(\mathrm{NO}_{\max }\right.$ : $51.02 \pm 0.63 \mathrm{nM} ; \mathrm{N}_{2} \mathrm{O}_{\max }$ : $95.13 \pm 5.97 \mathrm{nM}$ ), which dropped to background semi-steady state levels that were maintained until depletion of $\mathrm{N}$-oxides. As seen previously, $\mathrm{N}_{2}$ increased exponentially during early anoxia, then at linear or declining rate until depletion of added nitrate (Figure 4A). The activity of NirK (seen as e- flow to nitrite, $\mu \mathrm{mol}$ vial $^{-1} \mathrm{~h}^{-1}$ ), slowed prior to, and more dramatically than Nar (Figure 4C), which led to transient nitrite accumulation $\left(\mathrm{NO}_{2}{ }^{-}{ }_{\max }: 67.56 \mu \mathrm{M} \mathrm{vial}^{-1}\right)$ during late anoxia (Figure 4A).

The structural denitrification genes showed contrasting expression profiles. Unlike nirK and nor $Z$ whose expression showed a slight decline during the first $10 \mathrm{~h}$ of the incubation, narG and nos $Z$ transcription both increased by an order of magnitude within the first $3 \mathrm{~h}$ after inoculation and remained elevated throughout the semi-aerobic phase (Figure 4B, insert). Immediately before the transient $\mathrm{NO}$ and $\mathrm{N}_{2} \mathrm{O}$ peaks, nar $G$ and 
A

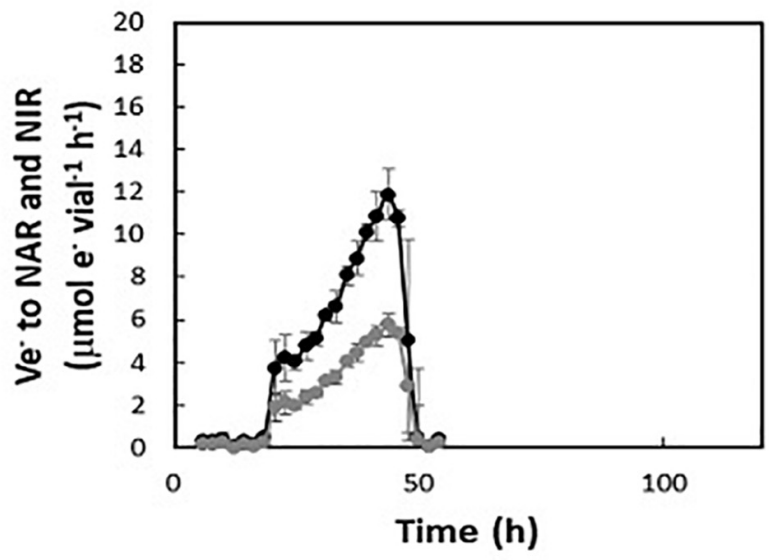

B

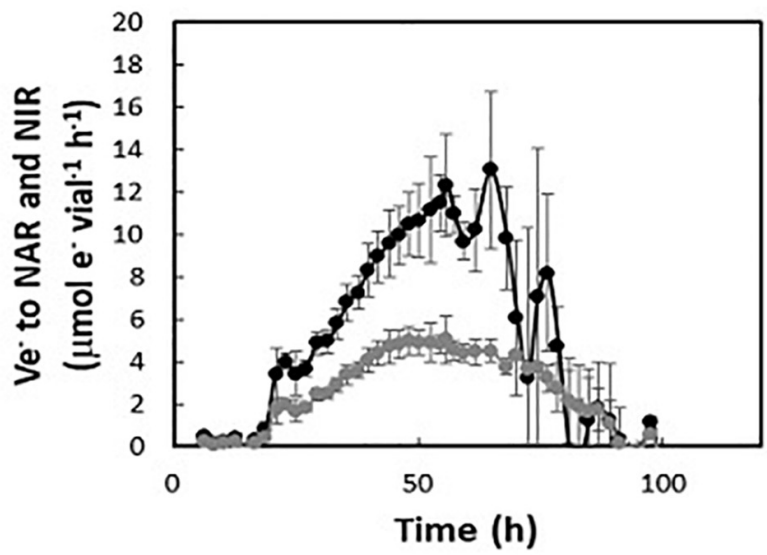

C

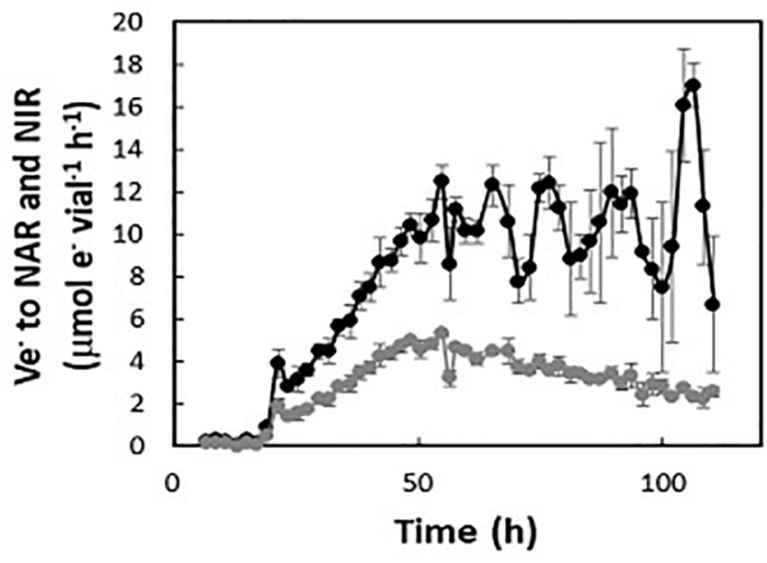

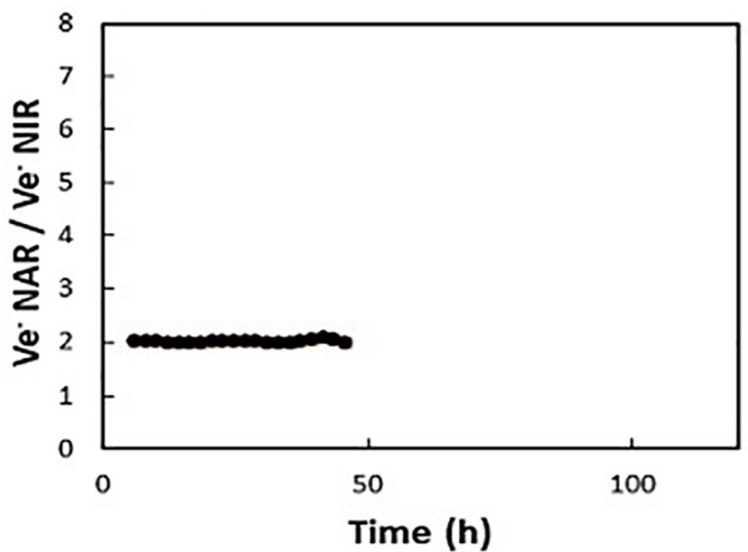
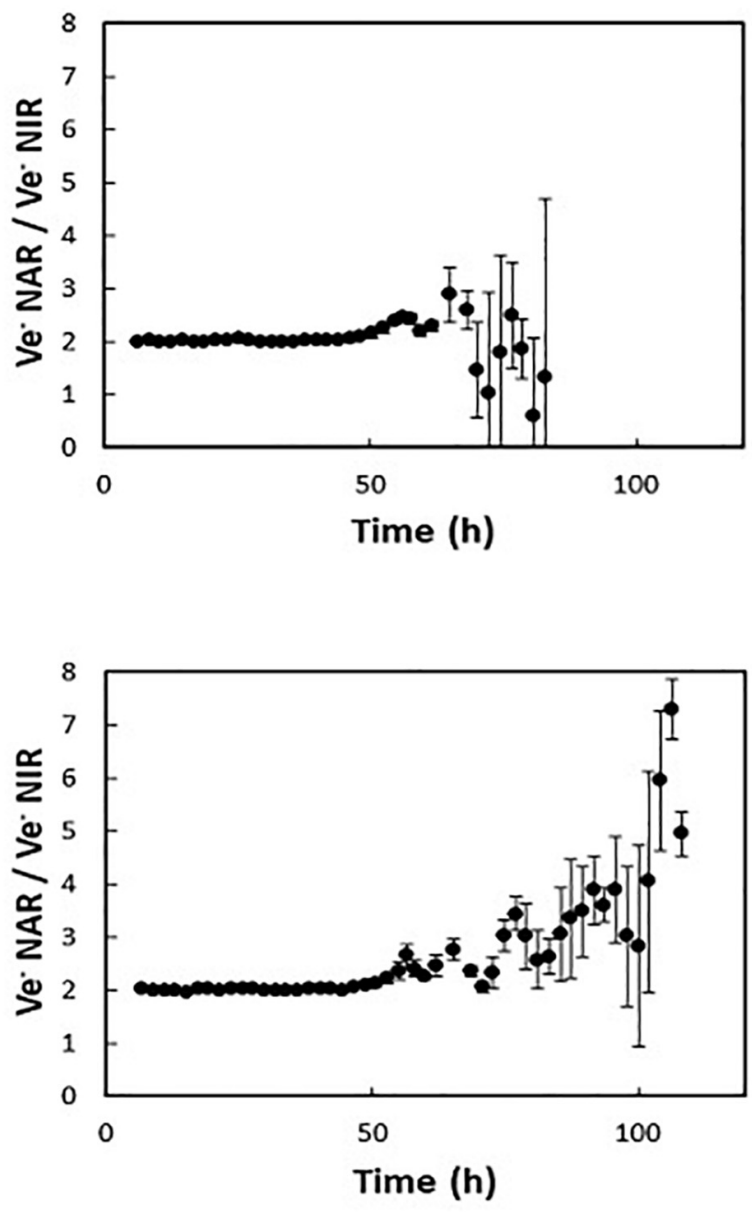

FIGURE 2 | Electron flow $\left(\mathrm{V}_{\mathrm{e}_{-}}, \mu \mathrm{mol} \mathrm{e}^{-}\right.$vial $\left.{ }^{-1} \mathrm{~h}^{-1}\right)$ to respiratory nitrate reductase (NAR-black lines) and nitrite reductase (NIR-gray lines) during the oxic-anoxic transition in batch cultures with $1 \%$ initial $\mathrm{O}_{2}$ and different initial $\mathrm{KNO}_{3}$ concentrations (left panels): $2 \mathrm{mM}$ (A), $5 \mathrm{mM}$ (B), $10 \mathrm{mM}$ (C). Right panels show the respective ratios between the electron flow to NAR and NIR.

nos $Z$ transcription increased by another order of magnitude, peaking at $7.5 \mathrm{E} 4 \pm 7.3 \mathrm{E} 2$ and $9.2 \mathrm{E} 4 \pm 4.0 \mathrm{E} 4$ copies $\mathrm{ng}^{-1}$ RNA, respectively. Transcription of $n a r G$ subsequently decreased and was kept at a reasonably constant number $(4.9 \mathrm{E} 3 \pm 1.7 \mathrm{E} 3$ copies $\mathrm{ng}^{-1}$ RNA) during the anoxic phase. As NO peaked, nos $Z$ reached a maximum of $1.8 \mathrm{E} 5 \pm 4.1 \mathrm{E} 4$ copies $\mathrm{ng}^{-1}$ RNA. 
A

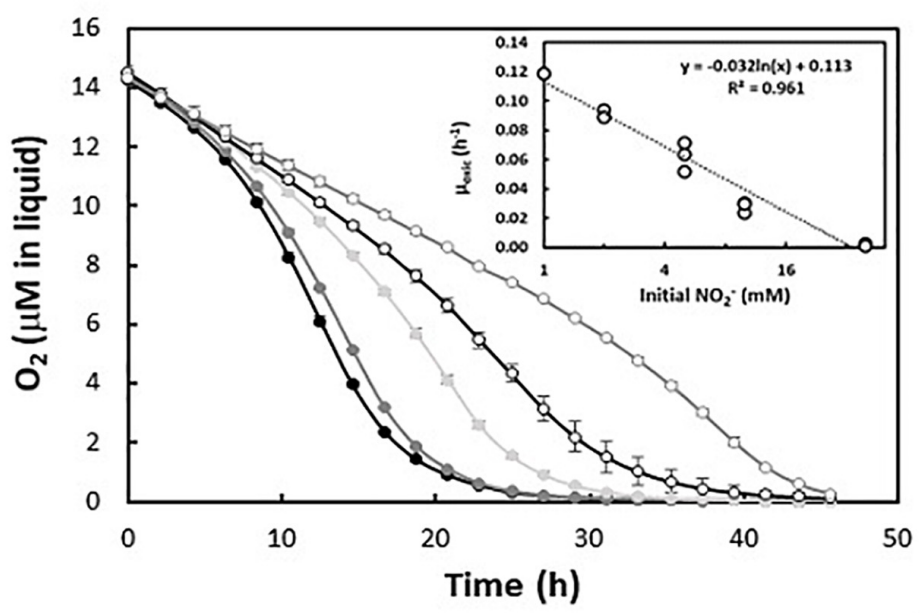

B
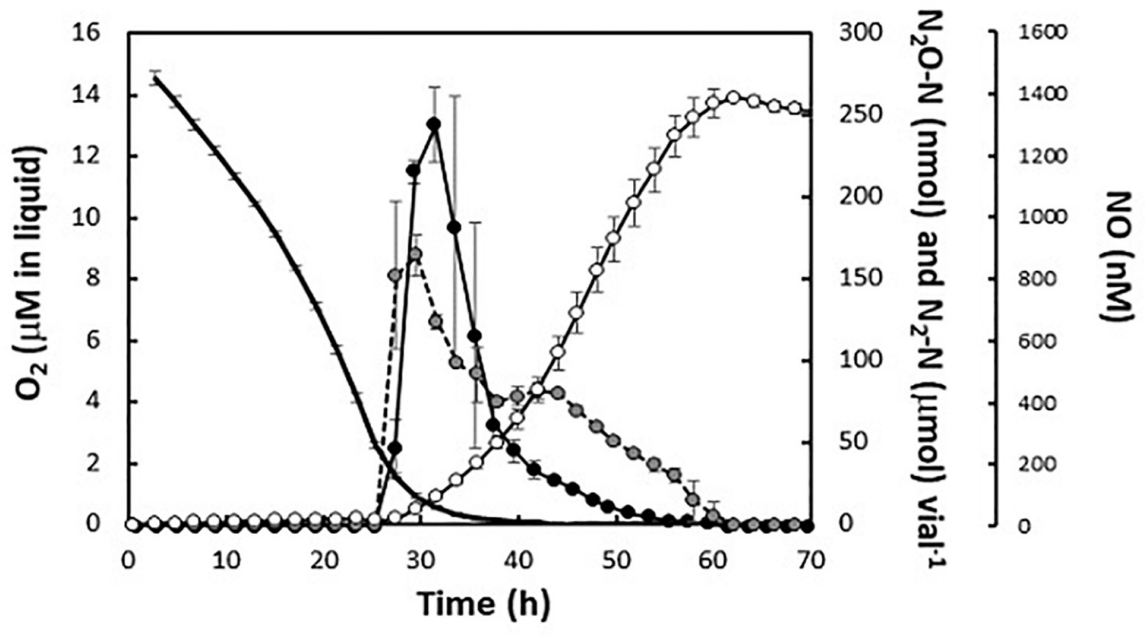

C

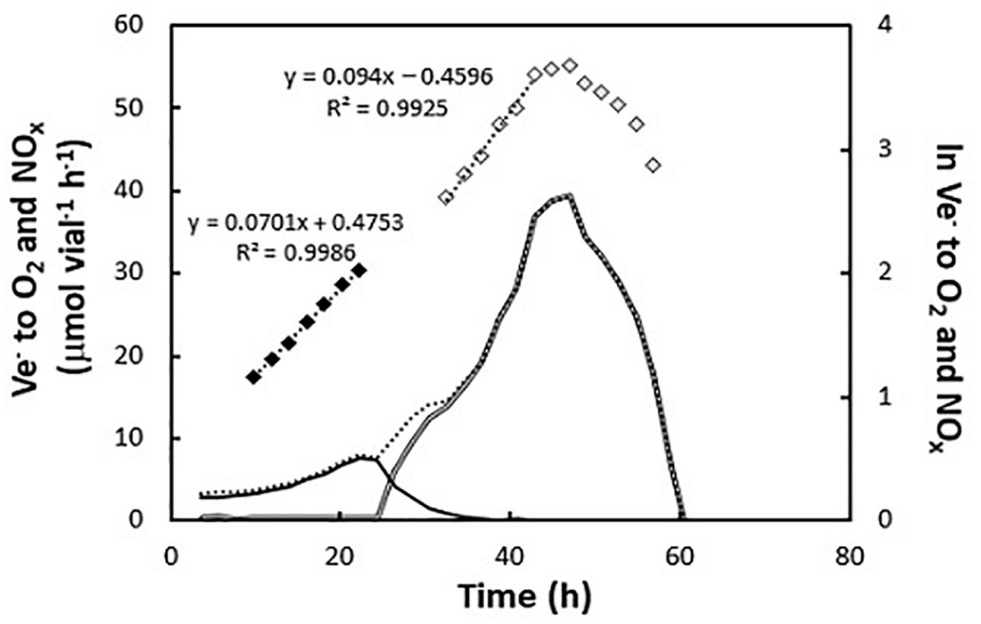

FIGURE 3 | Gas kinetics in cultures supplied with nitrite. (A) $\mathrm{O}_{2}$ consumption during the incubation of $H$. mediterranei in the presence of $1 \mathrm{mM}$ (black circles), $2 \mathrm{mM}$ (dark gray circles), $5 \mathrm{mM}$ (light gray circles), $10 \mathrm{mM}$ (open black circles), and $40 \mathrm{mM}$ (open gray circles) $\mathrm{KNO}_{2}$. Insert: apparent specific anaerobic growth rates $\left(\mu_{\text {anox }}, \mathrm{h}^{-1}\right)$ during log linear growth in the cultures with different initial $\mathrm{KNO}_{2}$ concentrations (1-40 mM). (B) Detailed gas kinetics during transition to anoxia in nitrite-supplemented medium $\left(5 \mathrm{mM} \mathrm{KNO}_{2}\right.$ ) with $1 \%$ initial $\mathrm{O}_{2}$ in headspace. Top panel: consumption of $\mathrm{O}_{2}$ (black line, no symbols) and subsequent accumulation of $\mathrm{N}$-oxides (NO-closed black circles; $\mathrm{N}_{2} \mathrm{O}$-closed gray circles; $\mathrm{N}_{2}$-open circles). The experiment was conducted at $35^{\circ} \mathrm{C}$ and in triplicate batch cultures. (C) E-flow $\left(\mathrm{V}_{\mathrm{e}-}, \mu \mathrm{mol}\right.$ vial ${ }^{-1} \mathrm{~h}^{-1}$ ) to $\mathrm{O}_{2}$ (black line) and $\mathrm{N}$-oxides (double black line) in representative batch culture with $5 \mathrm{mM} \mathrm{KNO}_{2}$ and $1 \%$ initial $\mathrm{O}_{2}$. Diamonds represent the regression of log (In) transformed respiration rates versus time during log-linear increases in electron transport rates (black diamonds for aerobic respiration and gray diamonds for anaerobic respiration). 


\section{A}

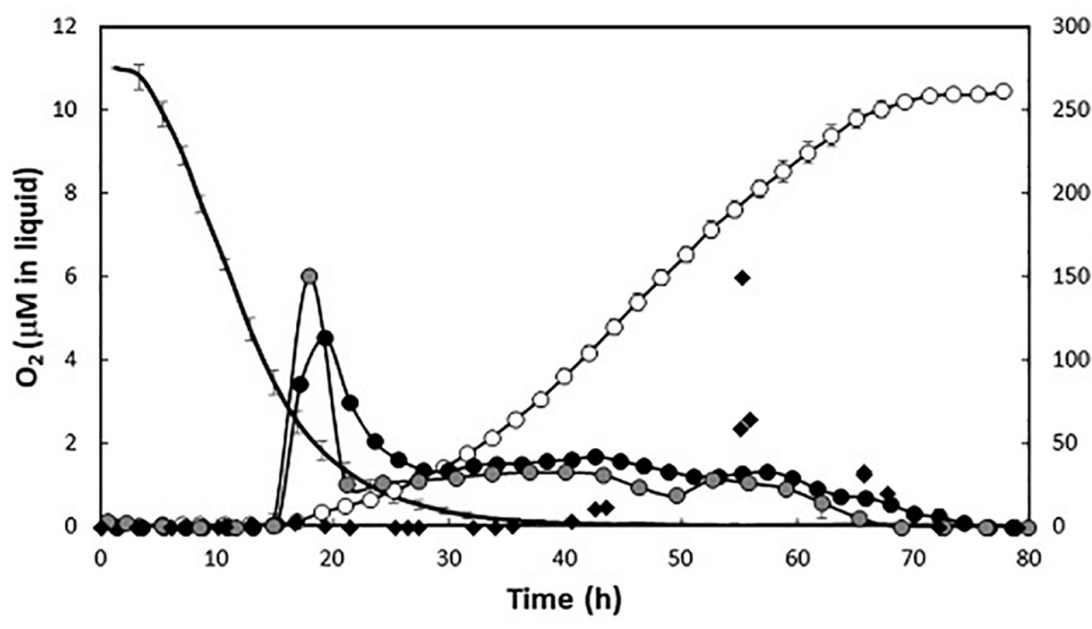

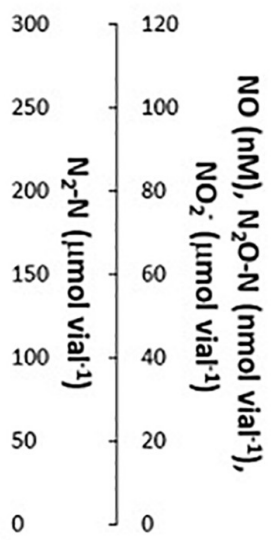

B

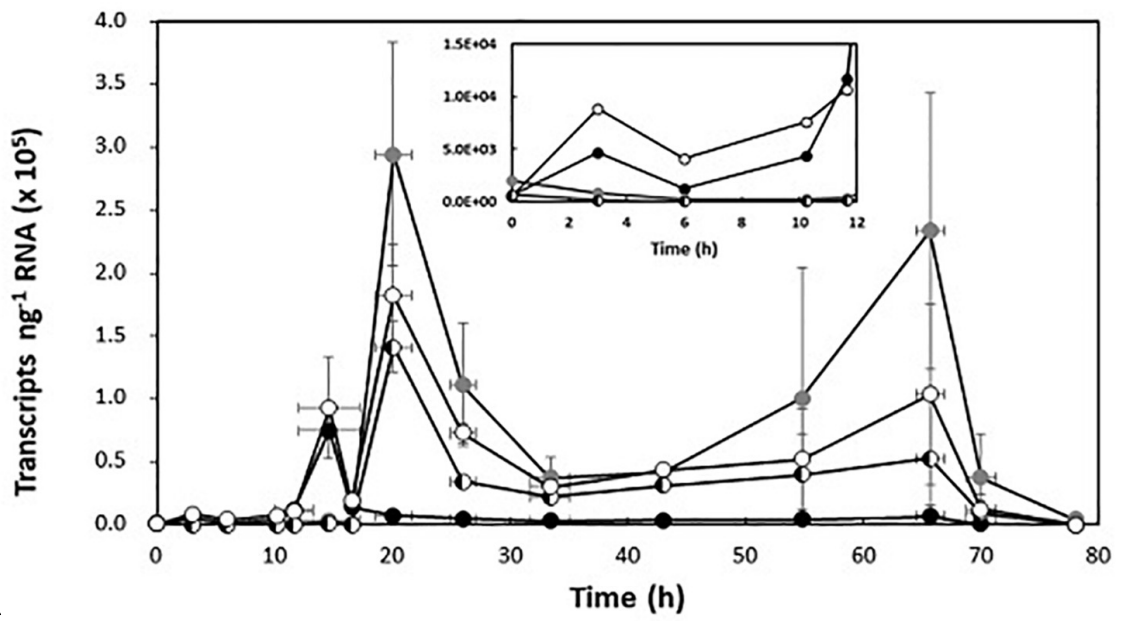

C

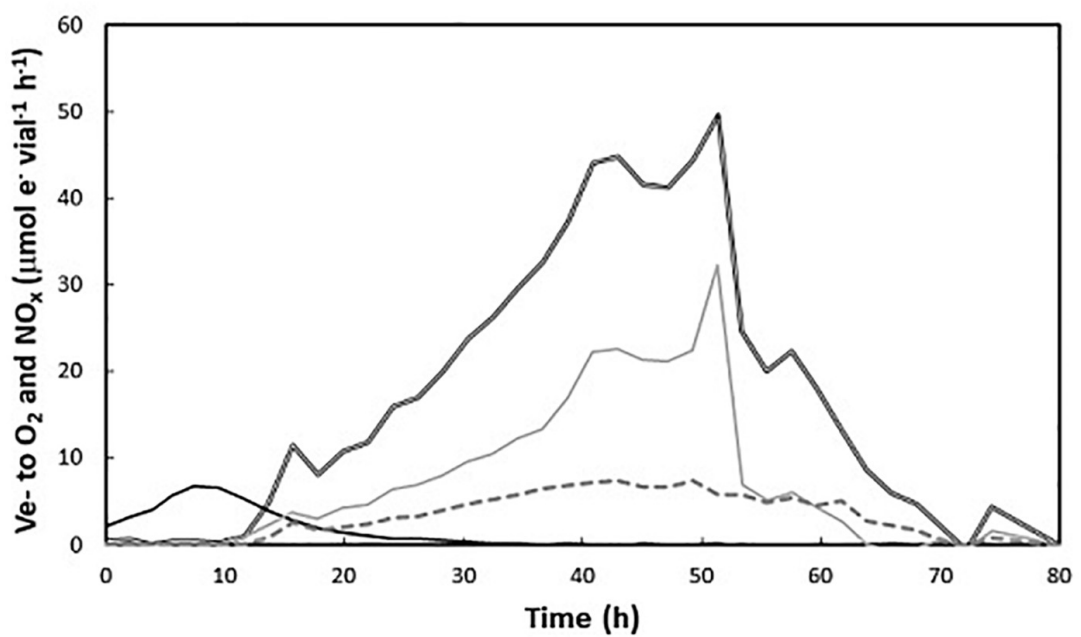

FIGURE 4 | Gas kinetics, gene transcription, and electron flow through the transition from aerobic to anaerobic respiration. (A) Consumption of $\mathrm{O}_{2}$ (black line, no symbols) and subsequent accumulation of $\mathrm{N}$-oxides $\left(\mathrm{NO}_{2}{ }^{-}\right.$- black diamonds; $\mathrm{NO}$-closed black circles; $\mathrm{N}_{2} \mathrm{O}$-closed gray circles; $\mathrm{N}_{2}-$ open circles) in nitrate-supplemented medium $\left(5 \mathrm{mM} \mathrm{KNO}_{3}\right)$ with $1 \%$ initial $\mathrm{O}_{2}$ in headspace $(n=3)$. (B) Number of gene transcripts per nanogram RNA which is shown with standard deviation as vertical lines $(n=3)$ (narG-closed black circles; nirk - closed gray circles; norZ - half white and half black circles; and nos $Z$-open white circles). The large deviations were due to an overall higher signal during active denitrification from one of the three replicate series. The sample at time 0 is the result for the inoculum (prior to inoculation). (C) Electron flow ( $\mu \mathrm{mol}$ vial ${ }^{-1} \mathrm{~h}^{-1}$ ) to $\mathrm{O}_{2}$ (black line), nitrate reductase (gray line), nitrite reductase (discontinuous gray line), and total $\mathrm{N}$-oxides (double black line). 
This coincided with high expression of nirK and nor $Z$, which both increased from background levels (fluctuating around $1 \mathrm{E} 2$ copies $\left.\mathrm{ng}^{-1} \mathrm{RNA}\right)$ to $2.9 \mathrm{E} 5 \pm 8.9 \mathrm{E} 4$ and $1.4 \mathrm{E} 5 \pm 2.0 \mathrm{E} 4$ copies $\mathrm{ng}^{-1}$ RNA, respectively. The nirK, nor $Z$, and nos $Z$ transcription maxima were followed by a period of exponential $\mathrm{N}_{2}$ accumulation, during which the expression of all three genes gradually dropped by an order of magnitude. As the apparent growth rate by denitrification declined, resulting in linear $\mathrm{N}_{2}$ accumulation after approximately $40 \mathrm{~h}$, the transcription of denitrification genes showed a subtle, and variable increase, particularly visible in nirK. Gene expression dropped to low levels (1E0-1E3 copies $\left.\mathrm{ng}^{-1} \mathrm{RNA}\right)$ after nitrate depletion (78 h).

\section{$\mathrm{N}_{2}$ OR Activity During the Semi-Aerobic Phase}

The early expression of nos $Z$ begs the question whether N2OR is active in the presence of $\mu \mathrm{M}$ concentrations of $\mathrm{O}_{2}$, preceding the "upstream" enzymes NIR and NOR. To test this, aerobically grown cells were transferred to vials injected with approximately 1 vol\% each of $\mathrm{O}_{2}$ and $\mathrm{N}_{2} \mathrm{O}$ in headspace and containing $5 \mathrm{mM} \mathrm{KNO}_{3}$ in the medium. Due to differences in solubility, the initial concentrations of $\mathrm{O}_{2}$ and $\mathrm{N}_{2} \mathrm{O}$ in the liquid were approximately 9 and $20 \mu \mathrm{M}$, respectively. During the first $8 \mathrm{~h}$ after inoculation, the decrease in $\mathrm{N}_{2} \mathrm{O}$ was chiefly attributable to dilution by sampling. However, as $\mathrm{O}_{2}$ concentration reached approximately $50 \%$ of the initial concentration $(4.13 \mu \mathrm{M}$ in liquid), $\mathrm{N}_{2} \mathrm{O}$ was rapidly reduced and its exhaustion coincided with the appearance of $\mathrm{NO}$ (Figure 5). The $\mathrm{O}_{2}$ and $\mathrm{N}_{2} \mathrm{O}$ reduction rates were used to estimate the respective electron flow rates $\left(\mathrm{Ve}^{-}, \mu \mathrm{mol} \mathrm{e}^{-1}\right.$ vial $^{-1} \mathrm{~h}^{-1}$ ) to $\mathrm{O}_{2}$ and $\mathrm{N}_{2} \mathrm{O}$ (Figure 5, insert). Initially, the electron flow was directed toward $\mathrm{O}_{2}$ as the only terminal acceptor. However, following the peak in $\mathrm{Ve}$ - to $\mathrm{O}_{2}$ (at approximately $9 \mathrm{~h}$ ) $\mathrm{Ve}$ - to $\mathrm{N}_{2} \mathrm{O}$ increased and peaked while $\mathrm{Ve}$ - to $\mathrm{O}_{2}$ was still at approximately $50 \%$ of the observed maximum. Thus, there was parallel respiration of $\mathrm{O}_{2}$ and $\mathrm{N}_{2} \mathrm{O}$ for several hours, apparently preceding induction of NIR (NO increase), reflecting the observed early transcription of nos $Z$.

\section{DISCUSSION}

Denitrifying organisms are widespread and highly diverse. Even so, detailed studies of their physiology and biochemistry have chiefly been limited to a relatively small number of bacteria with mesophilic lifestyles. Thus, the knowledge of this pathway in extremophilic microorganisms, especially archaea, is scarce. The first studies on this topic in haloarchaea were reported in the late eighties, last century, using Haloferax species, and mainly Haloferax denitrificans, as microbe of study (Mancinelli and Hochstein, 1986; Tomlinson et al., 1986). At that time, it was shown that $H$. denitrificans was capable of anaerobic growth in the presence of nitrate (or nitrite) and that this was accompanied by the production of dinitrogen. In the presence of high concentrations of nitrate (i.e., $0.5 \%$ ), nitrous oxide and nitrite were also detected (Tomlinson et al., 1986). During the last decade, denitrification in haloarchaea has gained new attention (Nájera-Fernández et al., 2012; Oren and Hallsworth, 2014;
Torregrosa-Crespo et al., 2016). Recently, H. mediterranei was identified as a promising candidate model organism for haloarchaeal denitrification (Torregrosa-Crespo et al., 2019) and the present study elaborates on its respiratory physiology.

Haloferax mediterranei maintained aerobic growth in the presence of high nitrate ( $\mathrm{mM}$ to $\mathrm{M}$ ) and $\mathrm{mM}$ nitrite concentrations, although negatively affected by the latter (Figure 3A and Supplementary Figure S1). During the transition to denitrification and subsequent nitrate/nitrite respiration, it displayed a robust phenotype in terms of accumulation of $\mathrm{N}$-oxide intermediates at near-neutral $\mathrm{pH}$ and with $\mathrm{mM}$ concentrations of $\mathrm{N}$-oxyanions in the medium. Initial nitrate concentration had little effect on transient NO accumulation and no discernible effect on the NO concentration during the anoxic phase (Figure 1A), reflecting a wellorchestrated denitrification apparatus tuned to control the accumulation of the most toxic intermediate. In contrast, and not unexpectedly, high initial nitrite concentrations did have a clear positive effect on NO accumulation. Even so, NO toxicity apparently only came into play for the highest concentrations tested, in which case it led to complete arrest (10 and $40 \mathrm{mM} \mathrm{NO}_{2}^{-}$Supplementary Figure S4). Thus, $H$. mediterranei is an organism showing a tolerance to nitrite like many heterotrophic denitrifiers (Chen et al., 2008, 2009; Nájera-Fernández et al., 2012).

Haloferax mediterranei was robust when facing high $\mathrm{N}$-oxyanion concentrations in near-neutral medium $(\mathrm{pH}=7.3)$ but was sensitive to acidification. When $\mathrm{pH}$ decreased from 7.3 to 6.5 in cultures supplemented with nitrate, there was an apparent generalized inhibition of all the $\mathrm{N}$-oxide reductases (Supplementary Table S2A). This contrasts with other denitrifiers, such as Paracoccus denitrificans, where subneutral $\mathrm{pH}$ affects the function of $\mathrm{N}_{2} \mathrm{OR}$ more than the rest of the denitrification enzymes (Bergaust et al., 2010). When nitrite was added to the medium, $H$. mediterranei could not grow at the lowest $\mathrm{pH}$ values (6.0 and 5.7). In these cultures, cells could not even consume $\mathrm{O}_{2}$ as final electron acceptor. This may have been due to the formation of toxic substances, a candidate being nitrous acid $\left(\mathrm{HNO}_{2}\right)$ derived from the protonation of nitrite at low pH (Reddy et al., 1983; Almeida et al., 1995).

A striking phenotypic trait was the conspicuous and reproducible decline in apparent specific growth rate after 1.5-2 generations of anoxic growth, irrespective of remaining nitrate/nitrite in the medium. This likely reflected lack of de novo synthesis of denitrification enzymes and thus dilution of per cell concentrations of the $\mathrm{N}$-oxide reductases during subsequent cell division. From the observed accumulation of nitrogenous gases, and a steady increase in nitrite during late anoxia (Figures 2, 4A), restraint of NIR synthesis appeared to marginally precede, and be more dramatic than, the decline in NAR synthesis. Moreover, the subsequent declining rate of e- flow toward NIR indicates net degradation of the existing enzyme pool. This effect was less dramatic in NAR, suggesting that the enzyme is less prone to degradation under these conditions. Lack of de novo synthesis would not necessarily result in any immediate decline in cell growth. This would depend on the margin by which the actual number of proteins per cell exceeds the critical 


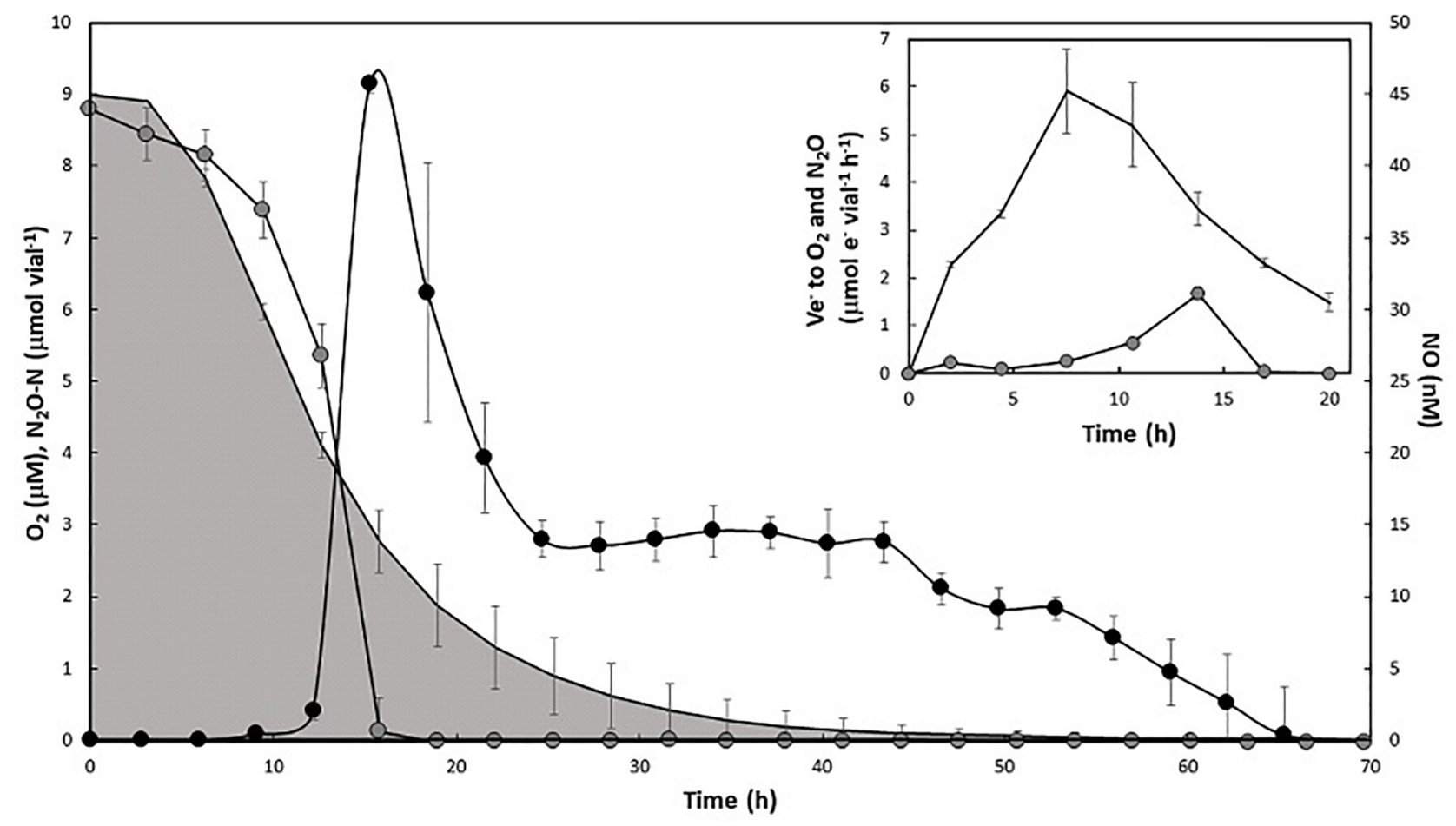

FIGURE 5 | Aerobic $\mathrm{N}_{2} \mathrm{O}$ reduction in aerobically pre-cultured cells with $1 \% \mathrm{~N}_{2} \mathrm{O}$ and $\mathrm{O}_{2}$ injected in the headspace. Main panel: $\mathrm{O}_{2}$ concentration in liquid $(\mu \mathrm{M}$, shaded area), $\mathrm{N}_{2} \mathrm{O}-\mathrm{N} \mathrm{\mu mol} \mathrm{vial}{ }^{-1}$ (gray circles), and $\mathrm{NO} n \mathrm{nM}$ in liquid (black circles). Standard deviation $(n=4)$ is shown as vertical lines. Insert: estimated rates of electron flow $\left(\mathrm{Ve}^{-}, \mu \mathrm{mol} \mathrm{e}^{-}\right.$vial $^{-1} \mathrm{~h}^{-1}$ ) to $\mathrm{O}_{2}$ (black line, no symbol) and $\mathrm{N}_{2} \mathrm{O}$ (gray circles) during the first $20 \mathrm{~h}$ of incubation.

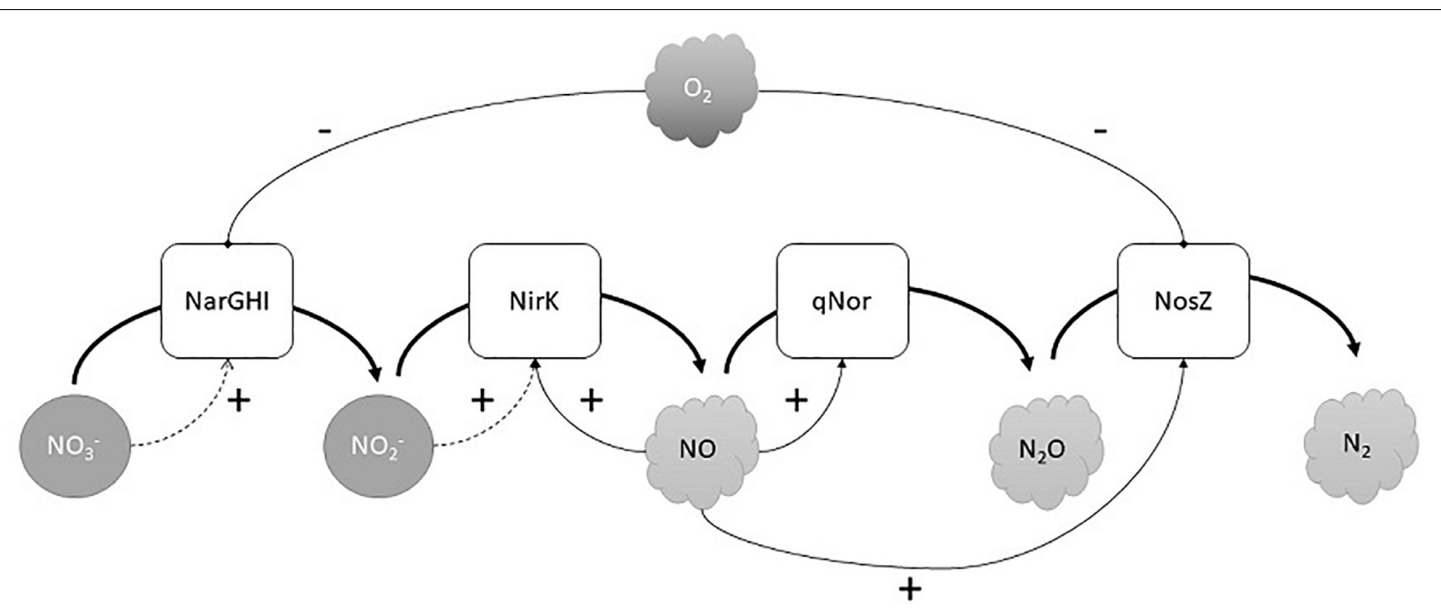

FIGURE 6 | Tentative regulatory model of denitrification in H. mediterranei. (+) means a positive regulation; (-) means negative regulation.

number required to operate the metabolic machinery at normal rate. Cell/biomass yield per mole nitrate reduced to $\mathrm{N}_{2}$ was not significantly affected by denitrification rate (Supplementary Figure S5). However, in complex systems, failure to maintain de novo synthesis of denitrification enzymes would likely be a competitive disadvantage.

The observation that NAR outperforms NIR is reconcilable with previous work showing that the haloarchaeal NAR is a robust enzyme operating at high rates (Lledó et al., 2004;
Martínez-Espinosa et al., 2007). However, the mechanisms underlying the apparent failure to maintain exponential growth (as seen by the activity of the enzyme pool) during denitrification (Figure 1B) are elusive. The transcription data (Figure 4) rule out any direct downregulation of $\mathrm{N}$-oxide reductase genes, and the decline was clearly not caused by nitrate limitation because it occurred irrespective of residual nitrate (up to high $\mathrm{mM}$ range) in the medium. Moreover, it was unlikely to be due to lack of nutrients because (i) the experiments were conducted in complex 
medium and (ii) previous results show that in cultures with higher initial oxygen ( 7 vol\%) and thus higher cell density, $5 \mathrm{mM}$ nitrate was reduced to $\mathrm{N}_{2}$ without any premature decline in growth rate (Supplementary Figure S6). However, in contrast to cultures with $1 \%$ initial $\mathrm{O}_{2}$, cultures with $7 \% \mathrm{O}_{2}$ depleted the available nitrate while conditions remained micro-oxic. Inspection of gas data from cultures with $1 \%$ initial oxygen shows that the decline in anaerobic growth rate typically co-occurs with oxygen exhaustion $\left(\left[\mathrm{O}_{2}\right]<0.1 \mu \mathrm{M}\right.$ in liquid). However, if microoxic conditions are required for de novo synthesis of $\mathrm{N}$-oxide reductases, the critical threshold is likely considerably higher than $0.1 \mu \mathrm{M} \mathrm{O}_{2}$ because any observable effect would be delayed. The apparent $\mathrm{O}_{2}$ threshold for induction of denitrification increases with initial concentration and has been observed to be $>20 \mu \mathrm{M}$ in cultures with $7 \%$ initial oxygen. In such cultures, $\mathrm{O}_{2}$ still remained at concentrations of approximately $5 \mu \mathrm{M}$ in the liquid at depletion of N-oxides (Supplementary Figure S6). Put together, the data suggest that $H$. mediterranei requires the presence of low $\mu \mathrm{M}$ concentrations of oxygen for de novo synthesis of denitrification enzymes (NAR and NIR), and that this regulation/effect is post-transcriptional. In fact, we did observe an increase, albeit subtle, in e- flow to $\mathrm{N}$-oxides after $\mathrm{O}_{2}$ injection to anaerobic cultures (Supplementary Figure S2).

To begin to understand the transcriptional regulation of denitrification in $H$. mediterranei, we quantified the expression of narG, nirK, nor $Z$, and nos $Z$ during the oxic-anoxic transition and subsequent anaerobic growth. Sampling was guided by observed gas kinetics, yielding a high-resolution profile of gene expression vs denitrification activity. Both narG and nos $Z$ appeared to be induced directly by hypoxia and did not require the presence of NO or nitrite for expression (Figure 4). Thus, narG and $n o s Z$ are likely activated via an oxygen (and possibly nitrate) sensor. The negative regulation of $\mathrm{NAR}$ by $\mathrm{O}_{2}$ via $\mathrm{O}_{2}$-sensing transcription factors is common in denitrifying bacteria (Spiro, 2012) and has also been observed for $\mathrm{N}_{2}$ OR (Bergaust et al., 2010, 2012). In $H$. mediterranei, the AcrR-like transcriptional regulator occupies the same position as the NarO regulator in Haloferax volcanii, recently identified as a putative $\mathrm{O}_{2}$ sensor in this strain (Hattori et al., 2016). The "core" reductases, NIR and NOR, were not induced by hypoxia alone, but apparently required the presence of NO (and possibly nitrite). The appearance of $\mathrm{NO}$ also coincided with a second peak in nos $Z$ transcription. Thus, nirK, nor $Z$, and nos $Z$ all appear to be under the control of unknown $\mathrm{NO} /$ nitrite sensor(s), again resembling bacterial denitrifiers in their regulatory circuits (van Spanning et al., 1999; Zumft, 2002). Positive nirK regulation by nitrite may underlie the second peak in nirK expression during late anoxia when nitrite accumulates (Figure 4). Due to the sequential nature of denitrification, it seems intuitive that the synthesis of $\mathrm{N}$-oxide reductases follows the same order. This has been shown to not always be the case in bacteria, where N2OR activity may precede NIR and NOR during the transition to anoxia (Qu et al., 2016). H. mediterranei displayed a similar phenotype where active $\mathrm{N}_{2} \mathrm{OR}$ was produced during the semi-aerobic phase, independent of $\mathrm{NO} /$ nitrite induction (Figure 5). The transcriptional regulation of denitrification in $H$. mediterranei is tentatively summarized in Figure 6.
Haloferax mediterranei emerges as a suitable model organism for the study of denitrification in saline and hypersaline environments. It tolerates the presence of high concentrations of nitrates and nitrites at optimum $\mathrm{pH}$ but appears to require microoxic conditions to sustain anaerobic growth by denitrification. It seems, as previous studies point out (Chen and Strous, 2013), that denitrification is not an entirely anaerobic process in all organisms. In some organisms such as $H$. mediterranei, instead of providing an exclusive and separate alternative to oxygen respiration, it may be a parallel process under micro-oxic conditions as a means to derive additional energy, but ineffective under strict anoxia. More studies will be needed to confirm the hypothesized requirement for oxygen for de novo synthesis of $\mathrm{N}$-reductases. $H$. mediterranei appears to have many regulatory traits in common with its bacterial counterparts, but in-depth molecular, physiological, and biochemical studies are still needed to understand the respiratory metabolism of this extremophile.

\section{DATA AVAILABILITY STATEMENT}

All datasets generated for this study are included in the article/Supplementary Material.

\section{AUTHOR CONTRIBUTIONS}

RM-E and LB conceived the experiments, were the project administrators, and oversaw the funding acquisition. The design of the experiments was conducted by LB and JT-C. The experiments were done by JT-C. Results were analyzed by all the authors. All the authors contributed to the discussion of the results and manuscript writing.

\section{ACKNOWLEDGMENTS}

Some of the results here summarized are part of the Thesis (Torregrosa-Crespo, 2019) defended by JTC in September 2019 at the University of Alicante, Spain.

\section{FUNDING}

This work was funded by research grants from the MINECO Spain (CTM2013-43147R and RTI2018-099860-B-I00), VIGROB-309 (University of Alicante), and Generalitat Valenciana (ACIF 2016/077). JT-C was financed by the European Molecular Biology Organization (EMBO-Short Term Fellowship ASTF No: 331-2016) to carry out the experiments at the Norwegian University of Life Sciences (NMBU). LB was funded by The Research Council of Norway (Project No. 275389).

\section{SUPPLEMENTARY MATERIAL}

The Supplementary Material for this article can be found online at: https://www.frontiersin.org/articles/10.3389/fmicb.2020. 00768/full\#supplementary-material 


\section{REFERENCES}

Almeida, J. S., Júlio, S. M., Reis, M. A. M., and Carrondo, M. J. T. (1995). Nitrite inhibition of denitrification by Pseudomonas fluorescens. Biotechnol. Bioeng. 46, 194-201. doi: 10.1002/bit.260460303

Andrei, A. S., Banciu, H. L., and Oren, A. (2012). Living with salt: metabolic and phylogenetic diversity of archaea inhabiting saline ecosystems. FEMS Microbiol. Lett. 330, 1-9. doi: 10.1111/j.1574-6968.2012.02526.x

Bakken, L. R., Bergaust, L., Liu, B., and Frostegård, § (2012). Regulation of denitrification at the cellular level: a clue to understanding $\mathrm{N} 2 \mathrm{O}$ emissions from soils. Philos. Trans. R. Soc. Lond. B Biol. Sci. 367, 1226-1234. doi: 10.1098/rstb. 2011.0321

Bergaust, L., Mao, Y., Bakken, L. R., and Frostegård, Å (2010). Denitrification response patterns during the transition to anoxic respiration and posttranscriptional effects of suboptimal $\mathrm{pH}$ on nitrogen oxide reductase in Paracoccus denitrificans. Appl. Environ. Microbiol. 76, 6387-6396. doi: 10.1128/AEM.00608-10

Bergaust, L., Shapleigh, J., Frostegård, ̊̊, and Bakken, L. R. (2008). Transcription and activities of NOx reductases in Agrobacterium tumefaciens: the influence of nitrate, nitrite and oxygen availability. Environ. Microbiol. 10, 3070-3081. doi: 10.1111/j.1462-2920.2007.01557.x

Bergaust, L., van Spanning, R. J., Frostegård, Å, and Bakken, L. R. (2012). Expression of nitrous oxide reductase in Paracoccus denitrificans is regulated by oxygen and nitric oxide through FnrP and NNR. Microbiology 158, 826-834. doi: 10.1099/mic.0.054148-0

Bru, D., Sarr, A., and Philippot, L. (2007). Relative abundances of proteobacterial membrane-bound and periplasmic nitrate reductases in selected environments. Appl. Environ. Microbiol. 73, 5971-5974. doi: 10.1128/AEM.00643-07

Chen, C., Wang, A., Ren, N. Q., Kan, H., and Lee, D. J. (2008). Biological breakdown of denitrifying sulfide removal process in high-rate expanded granular bed reactor. Appl. Microbiol. Biotechnol. 81, 765-770. doi: 10.1007/ s00253-008-1720-y

Chen, C., Wang, A. J., Ren, N. Q., Lee, D. J., and Lai, J. Y. (2009). High-rate denitrifying sulfide removal process in expanded granular sludge bed reactor. Bioresour. Technol. 100, 2316-2319. doi: 10.1016/j.biortech.2008.10.023

Chen, J., and Strous, M. (2013). Denitrification and aerobic respiration, hybrid electron transport chain and co-evolution. Biochim. Biophys. Acta 1827, 136144. doi: 10.1016/j.bbabio.2012.10.002

DasSarma, S., Fleischman, E. M., and Rodríguez-Valera, F. (1995). "Media for halophiles," in Archaea, a Laboratory Manual, eds S. DasSarma and E. M. Fleishman (New York, NY: Cold Spring Harbor Laboratory Press), 225-230.

Edbeib, M. F., Wahab, R. A., and Huyop, F. (2016). Halophiles: biology, adaptation, and their role in decontamination of hypersaline environments. World J. Microbiol. Biotechnol. 32, 1-23. doi: 10.1007/s11274-016-2081-9

Hattori, T., Shiba, H., Ashiki, K., Araki, T., Nagashima, Y., Yoshimatsu, K., et al. (2016). Anaerobic growth of haloarchaeon Haloferax volcanii by denitrification is controlled by the transcription regulator NarO. J. Bacteriol. 198, 1077-1086. doi: 10.1128/JB.00833-15

Lledó, B., Martínez-Espinosa, R. M., Marhuenda-Egea, F. C., and Bonete, M. J. (2004). Respiratory nitrate reductase from haloarchaeon Haloferax mediterranei: biochemical and genetic analysis. Biochim. Biophys. Acta 1674, 50-59. doi: 10.1016/j.bbagen.2004.05.007

Mancinelli, R. L., and Hochstein, L. I. (1986). The occurrence of denitrification in extremely halophilic bacteria. FEMS Microbiol. Lett. 35, 55-58. doi: 10.1111/j. 1574-6968.1986.tb01498.x

Martínez-Espinosa, R. M., Dridge, E. J., Bonete, M. J., Butt, J. N., Butler, C. S., Sargent, F., et al. (2007). Look on the positive side! The orientation, identification and bioenergetics of "Archaeal" membrane-bound nitrate reductases. FEMS Microbiol. Lett. 276, 129-139. doi: 10.1111/j.1574-6968.2007. 00887.x

Martínez-Espinosa, R. M., Richardson, D. J., Butt, J. N., and Bonete, M. J. (2006). Respiratory nitrate and nitrite pathway in the denitrifier haloarchaeon Haloferax mediterranei. Biochem. Soc. Trans. 34(Pt 1), 115-117. doi: 10.1042/ BST0340115

Molstad, L., Dörsch, P., and Bakken, L. R. (2007). Robotized incubation system for monitoring gases (O2, NO, N2O, N2) in denitrifying cultures. J. Microbiol. Meth. 71, 202-211. doi: 10.1016/j.mimet.2007.08.011
Nájera-Fernández, C., Zafrilla, B., Bonete, M. J., and Martínez-Espinosa, R. M. (2012). Role of the denitrifying Haloarchaea in the treatment of nitrite-brines. Int. Microbiol. 15, 111-119. doi: 10.2436/20.1501.01.164

Ochoa-Hueso, R., Arrónez-Crespo, M., Bowker, M. A., Maestre, F. T., PérezCorona, M. E., Theobald, M. R., et al. (2014). Biogeochemical indicators of elevated nitrogen depositions in semiarid Mediterranean ecosystems. Environ. Monit. Assess. 186, 5831-5842. doi: 10.1007/s10661-014-3822-6

Oren, A. (2013). Life at high salt concentrations, intracellular $\mathrm{KCl}$ concentrations and acidic proteomes. Front. Microbiol. 4:315. doi: 10.3389/fmicb.2013. 00315

Oren, A., and Hallsworth, J. E. (2014). Microbial weeds in hypersaline habitats: the enigma of the weed-like Haloferax mediterranei. FEMS Microbiol. Lett. 359, 134-142. doi: 10.1111/1574-6968.12571

Philippot, L., Hallin, S., and Schloter, M. (2007). Ecology of denitrifying prokaryotes in agricultural soil. Adv. Agron. 96, 249-305. doi: 10.1016/S00652113(07)96003-4

Qu, Z., Bakken, L. R., Molstad, L., Frostegård, Å, and Bergaust, L. L. (2016). Transcriptional and metabolic regulation of denitrification in Paracoccus denitrificans allows low but significant activity of nitrous oxide reductase under oxic conditions. Environ. Microbiol. 18, 2951-2963. doi: 10.1111/1462-2920. 13128

Reddy, D., Lancaster, J. R., and Cornforth, D. P. (1983). Nitrite inhibition of Clostridium botulinum: electron spin resonance detection of iron-nitric oxide complexes. Science 221, 769-770. doi: 10.1126/science.6308761

Roco, C. A., Bergaust, L. L., Bakken, L. R., Yavitt, J. B., and Shapleigh, J. P. (2017). Modularity of nitrogen-oxide reducing soil bacteria: linking phenotype to genotype. Environ. Microbiol. 19, 2507-2519. doi: 10.1111/1462-2920. 13250

Rodríguez-Valera, F., Ruiz-Berraquero, F., and Ramos-Cormenzana, A. (1980). Behaviour of mixed populations of halophilic bacteria in continuous cultures. Can. J. Microbiol. 26, 1259-1263. doi: 10.1139/m80-210

Rodríguez-Valera, F., Ventosa, A., Juez, G., and Imhoff, J. F. (1985). Variation of environmental features and microbial populations with salt concentration in a multi-pond saltern. Microb Ecol. 11, 107-115. doi: 10.1007/BF0201 0483

Samad, M. S., Bakken, L. R., Nadeem, S., Clough, T. J., de Klein, C. A., Richards, K. G., et al. (2016). High-resolution denitrification kinetics in pasture soils link $\mathrm{N} 2 \mathrm{O}$ emissions to $\mathrm{pH}$, and denitrification to $\mathrm{C}$ mineralization. PLoS ONE 11:e0151713. doi: 10.1371/journal.pone.0151713

Sherwood, J. E., Stagnitti, F., Kokkinn, M. J., and Williams, W. D. (1991). Dissolved oxygen concentrations in hypersaline waters. Limnol. Oceanogr. 36, 235-250. doi: 10.4319/lo.1991.36.2.0235

Sherwood, J. E., Stagnitti, F., Kokkinn, M. J., and Williams, W. D. (1992). A standard table for predicting equilibrium dissolved oxygen concentrations in salt lakes dominated by sodium chloride. Int. J. Salt Lake Res. 1, 1-6. doi: 10.1007/BF02904948

Spiro, S. (2012). Nitrous oxide production and consumption: regulation of gene expression by gas-sensitive transcription factors. Philos. Trans. R. Soc. Lond. B Biol. Sci. 367, 1213-1225. doi: 10.1098/rstb.2011.0309

Tomlinson, G. A., Jahnke, L. L., and Hochstein, L. I. (1986). Halobacterium denitrificans sp. nov., an extremely halophilic denitrifying bacterium. Int. J. Syst. Bacteriol. 36, 66-70. doi: 10.1099/00207713-36-1-66

Torregrosa-Crespo, J. (2019) Denitrification in haloarchaea: from genes to climate change. Thesis. University of Alicante. pp. 191. Available online at: http://rua. ua.es/dspace/handle/10045/99175 (accessed February 19, 2020).

Torregrosa-Crespo, J., Bergaust, L., Pire, C., and Martínez-Espinosa, R. M. (2018). Denitrifying haloarchaea: sources and sinks of nitrogenous gases. FEMS Microbiol. Lett. 365, 1-6. doi: 10.1093/femsle/fnx270

Torregrosa-Crespo, J., González-Torres, P., Bautista, V., Esclapez, J., Pire, C., Camacho, M., et al. (2017). Analysis of multiple haloarchaeal genomes suggests that the quinone-dependent respiratory nitric oxide reductase is an important source of nitrous oxide in hypersaline environments. Environ. Microbiol. Rep. 9, 788-796. doi: 10.1111/1758-2229.12596

Torregrosa-Crespo, J., Martínez-Espinosa, R. M., Esclapez, J., Bautista, V., Pire, C., Camacho, M., et al. (2016). Anaerobic metabolism in Haloferax genus: denitrification as case of study. Adv. Microb. Physiol. 68, 41-85. doi: 10.1016/ bs.ampbs.2016.02.001 
Torregrosa-Crespo, J., Pire, C., Martínez-Espinosa, R. M., and Bergaust, L. (2019). Denitrifying haloarchaea within the genus Haloferax display divergent respiratory phenotypes, with implications for their release of nitrogenous gases. Environ. Microbiol. 21, 427-436. doi: 10.1111/1462-2920. 14474

van Spanning, R. J., Houben, E., Reijnders, W. N., Spiro, S., Westerhoff, H. V., and Saunders, N. (1999). Nitric oxide is a signal for NNR-mediated transcription activation in Paracoccus denitrificans. J. Bacteriol. 181, 4129-4132. doi: 10.1128/ jb.181.13.4129-4132.1999

Walters, C. L., Gillatt, P. N., Palmer, R. C., and Smith, P. L. (1987). A rapid method for the determination of nitrate and nitrite by chemiluminescence. Food Addit. Contam. 4, 133-140. doi: 10.1080/02652038709373624

Zumft, W. G. (2002). Nitric oxide signaling and NO dependent transcriptional control in bacterial denitrification by members of the FNR-CRP regulatory family. J. Mol. Microbiol. Biotechnol. 4, 277-286.
Zumft, W. G., and Kroneck, P. M. (2006). Respiratory transformation of nitrous oxide (N2O) to dinitrogen by Bacteria and Archaea. Adv. Microb. Physiol. 52, 107-227. doi: 10.1016/S0065-2911(06)52003-X

Conflict of Interest: The authors declare that the research was conducted in the absence of any commercial or financial relationships that could be construed as a potential conflict of interest.

Copyright (c) 2020 Torregrosa-Crespo, Pire, Bergaust and Martínez-Espinosa. This is an open-access article distributed under the terms of the Creative Commons Attribution License (CC BY). The use, distribution or reproduction in other forums is permitted, provided the original author(s) and the copyright owner(s) are credited and that the original publication in this journal is cited, in accordance with accepted academic practice. No use, distribution or reproduction is permitted which does not comply with these terms. 